\title{
РЕЗУЛЬТАТИ УПРОВАДЖЕННЯ ЦИФРОВИХ ТЕХНОЛОГІЙ У ПРОФЕСІЙНУ ПІДГОТОВКУ МАЙБУТНІХ ФАХІВЦІВ В УМОВАХ $3 В О$
}

\author{
Інна Харченко \\ доктор педагогічних наук, доцент кафедри державно-правових дисциплін та \\ українознавства, \\ Сумський національний аграрний університет, \\ м. Суми, Україна \\ ORCID ID 0000-0010-0111-0125 \\ kharchenko-inna@ukr.net
}

Інна Шишенко

кандидат педагогічних наук, доцент кафедри математики, Сумський державний педагогічний університет імені А.С. Макаренка, м. Суми, Україна

ORCID ID 0000-0002-1026-5315

shiinna@ukr.net

\begin{abstract}
Анотація. У статті представлено результати упровадження цифрових технологій у освітній процес закладу вищої освіти. У межах спеціально створеного інформаційноосвітнього середовища ЗВО реалізується можливість використання сучасних інформаційних технологій та поглиблену інтеграцію засобів спеціалізованого професійного спрямування 3 якісним інформаційним забезпеченням усіх освітніх компонентів. Експериментальний освітній процес було структуровано таким чином, щоб знання студентів, професійні вміння і навички, потрібні для майбутньої професійної діяльності фахівцю, трансформувалися засобами цифрових технологій у високий рівень інформаційно-цифрової культури. Динаміка показника для експериментальної групи була кращою, а серед чинників, які сприяли такому покращенню, бачимо посилене використання інформаційних (електронних, дистанційних, мобільних) технологій навчання та постійне залучення інформаційно-освітнього середовища ЗВО для виконання самостійних завдань.
\end{abstract}

Ключові слова: професійна підготовка; цифрові технології; педагогічний експеримент; інформаційно-цифрова культура; майбутні фахівці.

Постановка проблеми в загальному вигляді. Нині модернізаційні зрушення в економіці визначають істотні зміни у вимогах роботодавців до підготовки випускників закладів вищої освіти. Роботодавці зазнають, що майбутні фахівці мають володіти компетентностями у царині обраної професії, бути вмотивованими, мати розвинені здатності до професійного зростання та високий рівень розвитку інформаційно-цифрової культури. За таких умов провідним завданням сучасної вищої освіти стає упровадження цифрових технологій в освітнє середовище, яке надасть можливість кожному майбутньому фахівцю побудувати індивідуальну освітню траекторію, що необхідна йому для

() ДВНЗ «Донбаський державний педагогічний університет» 
досягнення власної професійної мети та реалізації себе у професії та суспільстві. Тому побудова освітнього процесу в ЗВО на базі організації інформаційноосвітнього середовища $є$ одним із можливих шляхів розвитку професійної освіти.

Аналіз останніх досліджень і публікацій. М. Жалдак (Zhaldak, 2012), Н. Морзе (Morze, 2004), Є. Полат (Polat, 2015), О. Спірін (Spirin, 2007) та ін. переконливо довели, що упровадження цифрових технологій у освітній процес ЗВО передбачає швидке оновлення навчального контенту в контексті розвитку науки; якісне перетворення методів і форм навчання; здійснення оперативного моніторингу рівня пізнавальних можливостей і навчальних досягнень кожного; посилення міждисциплінарних зв'язків; збільшення обсягів самостійної роботи для кожного конкретного студента; створення можливості самоконтролю якості здобутих знань. У роботах цих авторів наголошено на необхідності актуалізації процесів вдосконалення освітніх програм в контексті сучасних вимог ринків освітніх послуг і професійної спільноти, значущими серед яких $є$ цифровізація та інформаційно-цифрові компетентності випускників. Авторами також розкриті механізми та організаційно-дидактичні умови підвищення якості професійної підготовки випускників в умовах цифровізації освітнього процесу, основні напрями розвитку електронного навчання на рівні вищої школи, особливості включення цифрових технологій на всіх рівнях навчально-пізнавальної діяльності як студентів бакалаврату, так і магістратури.

У межах спеціально створеного інформаційно-освітнього середовища ЗВО реалізується можливість сприяти розвитку професійної культури майбутніх фахівців загалом та ï складових через використання сучасних педагогічних та інформаційних технологій та поглиблену інтеграцію засобів спеціалізованого професійного спрямування 3 якісним інформаційним забезпеченням усіх освітніх компонентів.

Формулювання цілей статті (постановка завдання). Метою дослідження є представити результати упровадження цифрових технологій у освітній процес закладу вищої освіти як основи для розвитку інформаційноцифрової професійної культури майбутніх фахівців.

Методика дослідження. Методика статистичного опрацювання результатів педагогічного експерименту полягала в організації тестової перевірки знань. Респондентам пропонувалося 100 запитань, кожне 3 яких оцінювалося в 1 бал. Результати навчання розподіляються за рівнями наступним чином (табл. 1).

Професіоналізм педагога: теоретичні й методичні аспекти. - Вип. 16. - Слов’янськ, 2021. 
Таблиця 1

Відповідність сумарної кількості отриманих балів рівням цифрової підготовленості майбутніх фахівців

\begin{tabular}{|l|l|l|l|l|}
\hline Рівні & Базовий & Середній & Високий & Досконалий \\
\hline Бали & $0-20$ & $21-50$ & $51-80$ & $81-100$ \\
\hline
\end{tabular}

Тестування проводиться двічі: на початку і в кінці експерименту, на основі чого робляться висновки про ефективність запропонованих підходів.

Педагогічний експеримент проводився в Укркооспілки Хмельницькому кооперативному торговельно-економічному інституті, Херсонському національному технічному університеті, Сумському національному аграрному університеті, Вінницькому національному технічному університеті, Донецькому державному університеті управління, Мелітопольському державному педагогічному університеті імені Богдана Хмельницького, Комунальному закладі «Харківська гуманітарно-педагогічна академія» Харківської обласної ради, Сумському державному педагогічному університеті імені А. С. Макаренка, Приватному класичному університеті, Східноукраїнському національному університеті імені Володимира Даля. В експерименті брали участь 621 студент (галузі знань 05 «Соціальні та поведінкові науки» спеціальності 051 «Економіка» та галузі знань 07 «Управління та адміністрування» спеціальностей 072 «Фінанси, банківська справа та страхування» і 075 «Маркетинг»). Для проведення дослідження було сформовано експериментальні та контрольні групи відповідно до вимог експерименту, студенти яких знаходились у рівноцінних умовах.

Результати дослідження. Важливою умовою раціонального включення цифрових технологій в практику викладання фахових дисциплін $\epsilon$ модернізація всіх компонентів відповідних методичних систем. Необхідно відзначити цікаву тенденцію - розробку цифрового супроводу до традиційного друкованого видання, зокрема, електронний навчальний посібник. Цифрові технології та продукти дозволяють викладачеві та студентам по-новому виконувати, оформляти і зберігати дослідні проєкти інтегративного характеру у вигляді електронних файлів, в яких можна одночасно використовувати текст, обчислення і графічні зображення. Велика роль цифрових технологій в реалізації класичного дидактичного принципу навчання - принципу наочності. Зокрема, цифрові технології та продукти дозволяють створювати і використовувати в освітньому процесі анімації графічних об'єктів з високою роздільною здатністю. Значним дидактичним потенціалом володіють цифрові технології і продукти 
завдяки можливості проєктування та використання предметно орієнтованих баз даних та баз знань, призначених для побудови і дослідження математичних i імітаційних моделей, а також застосування кількісних методів при вирішенні прикладних задач (Лапчик, 2013).

Практика впровадження цифрових технологій в освітній процес ЗВО дозволяє зробити висновок про зв'язок найбільш істотних дидактичних принципів, педагогічних i методичних цілей i цифрових засобів. Зокрема, цифрові технології та ресурси освітнього призначення на основі цифрових технологій, впроваджені в практику викладання фахових дисциплін, сприяють:

- формуванню цифрових компетентностей на основі діяльнісного підходу до проєктованого освітнього процесу;

- реалізації принципів індивідуалізації і диференціації професійної підготовки при збереженні їі цілісності;

- зростання пізнавальної активності студентів при вивченні фахових дисциплін;

- активізації механізмів самоконтролю і самокорекції, в тому числі під час роботи з цифровими освітніми ресурсами;

- реалізації технологічної діагностики на всіх стадіях освітнього процесу;

- посилення усвідомленості в навчально-пізнавальної діяльності студентів, підвищенню їх інтелектуальних і логічних можливостей;

- підвищення мотивації при побудові імітаційних моделей, а також в процесі застосування кількісних методів;

- розвитку каналів обміну дидактичною інформацією як основи для корекції освітнього процесу;

- насиченню практики фахової підготовки принципово новими цифровими інструментами, які дозволяють реалізовувати недоступні раніше експерименти, будувати моделі при вирішенні прикладних задач, в тому числі, пов'язаних 3 майбутньою професійною діяльністю в умовах цифрової економіки.

Електронне навчання в інформаційно-освітньому середовищі ЗВО охоплює цілий спектр додатків і процесів. Воно осучаснює освітній процес, оскільки окрім очної частини і обов’язкової самостійної роботи суб'єктів учіння у ньому передбачено i віртуальну частину, яка реалізується 3 широким застосуванням Інтернет-технологій, що забезпечують доступність, надійність вибору і використання освітнього контенту, дозволяючи екстериторіально і у будь-який час отримувати консультації викладача, тьютора, організаторів навчання і спілкуватися з однокурсниками в навчальних форумах. Електронні освітні ресурси обумовлюють зміщення акцентів у технологіях навчання: від 
набуття знань до самостійної дослідницької роботи, до розвитку творчих якостей у суб'єктів навчання, що, в свою чергу, передбачає інноваційну методологічну перебудову системи оцінювання якості засвоєних знань та вмінь. Підтвердженням цьому $\epsilon$ факт збільшення кількості закладів освіти, які здійснюють підготовку з використанням інформаційних технологій. Також для ефективного функціонування інформаційно-освітнього середовища ЗВО відзначимо важливість інформаційних технологій навчання, до яких відносимо електронні, дистанційні та мобільні (Цідило, 2011).

Водночас зазначимо, що упровадження цифрових технологій в освітній процес 3ВО потребу, окрім координації дій для управління процесами інформатизації та підготовки викладачів до роботи в умовах інформаційноосвітнього середовища, також і цифрової підготовленості студентів на рівні, що дає їм змогу заглибитися у предметне середовище, моделювати, проєктувати, здійснювати інформаційний пошук засобами Інтернет-технологій. Тому нами було створено контрольну та експериментальну групи студентів, у яких проведено зрізи для визначення цифрової підготовленості студентів.

Студенти експериментальних груп навчалися за умов повсюдного упровадження цифрових технологій на кожному етапі освітнього процесу, а студенти контрольних груп продовжували навчання у традиційний спосіб. Експериментальний освітній процес було структуровано таким чином, щоб знання студентів, професійні вміння і навички, потрібні для майбутньої професійної діяльності фахівцю, трансформувалися засобами цифрових технологій у високий рівень інформаційно-цифрової культури.

Загальні результати розподілилися наступним чином (табл. 2, рис. 1):

Таблиця 2

Розподіл учасників за рівнями на початку експерименту

\begin{tabular}{|l|l|l|l|l|l|l|l|l|l|}
\hline \multirow{2}{*}{$\begin{array}{l}\text { Рівні } \\
\text { Групи }\end{array}$} & \multicolumn{2}{|l|}{ Базовий } & \multicolumn{2}{l|l|l|l|}{ Середній } & \multicolumn{2}{l|}{ Високий } & \multicolumn{2}{l|}{ Досконалий } & Разом \\
\cline { 2 - 10 } & К-ть & $\%$ & К-ть & $\%$ & К-ть & $\%$ & К-ть & $\%$ & \\
\hline ЕГ & 154 & $50,3 \%$ & 68 & $22,1 \%$ & 59 & $19,1 \%$ & 26 & $8,4 \%$ & 307 \\
\hline КГ & 177 & $56,5 \%$ & 81 & $25,8 \%$ & 42 & $13,6 \%$ & 13 & $4,2 \%$ & 314 \\
\hline
\end{tabular}




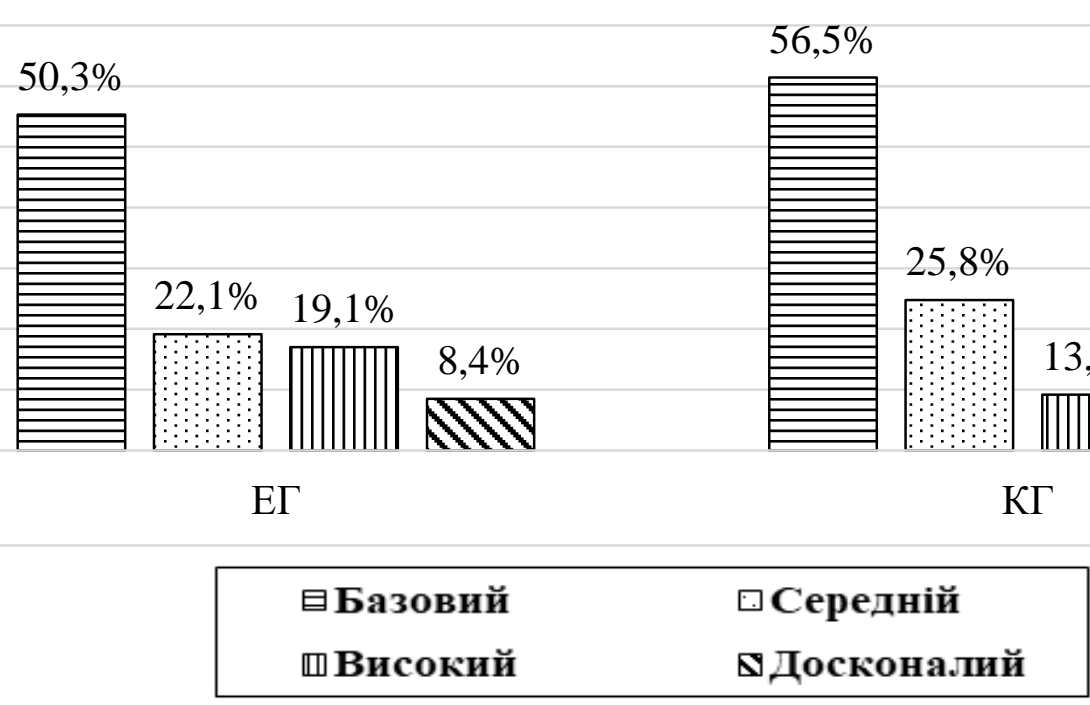

Рис. 1. Діаграма рівнів для ЕГ та КГ на початку експерименту

За діаграмою можна припустити, що вибірки статистично однакові. Перевіримо це на основі критерія Стьюдента для оцінки середніх 3 використанням статистичних функцій MS Excel (табл. 3).

Таблиця 3

\section{Оцінка середніх (на початку експерименту)}

\begin{tabular}{|l|l|l|}
\hline $\begin{array}{l}\text { Двовибірковий } \\
\text { 3 різними дисперсіями }\end{array}$ & $\mathbf{K} \boldsymbol{~} \mathbf{1 - т е с т ~}$ & $\mathbf{E \Gamma ~}$ \\
\hline Середнє & 55,275229358 & 56,510638298 \\
\hline Кількість & 314 & 307 \\
\hline Різниця середніх гіпотези $\mathrm{H}_{0}$ & 0 & \\
\hline t-статистика (експериментальне) & $-1,510348854$ & \\
\hline t критичне двостороннє & 1,972731033 & \\
\hline
\end{tabular}

За аналізом таблиці бачимо, що на рівні значущості $0,05 T_{\text {крит. }}=1,97 \mathrm{i}$ воно по модулю більше за $T_{\text {eксn. }}=-1,51$. Це означає, що вибірки статистично однаковими входять у педагогічний експеримент. У кінці експерименту знову було проведено подібний зріз знань, результати якого подані у таблиці 4 та на рисунку 2.

Таблиця 4

Розподіл учасників за рівнями після експерименту

\begin{tabular}{|l|l|l|l|l|l|l|l|l|l|}
\hline \multirow{2}{*}{ Групи Рівні } & \multicolumn{2}{l|}{ Базовий } & \multicolumn{2}{l|}{ Середній } & \multicolumn{2}{l|}{ Високий } & \multicolumn{2}{l|}{ Досконалий } & Разом \\
\cline { 2 - 11 } & \cline { 2 - 11 } \\
\cline { 2 - 11 } & К-ть & $\%$ & К-ть & $\%$ & К-ть & $\%$ & К-ть & $\%$ & \\
\hline КГ & 29 & $9,6 \%$ & 75 & $24,5 \%$ & 131 & $42,5 \%$ & 72 & $23,3 \%$ & 307 \\
\hline
\end{tabular}

Професіоналізм педагога: теоретичні й методичні аспекти. - Вип. 16. - Слов'янськ, 2021. 


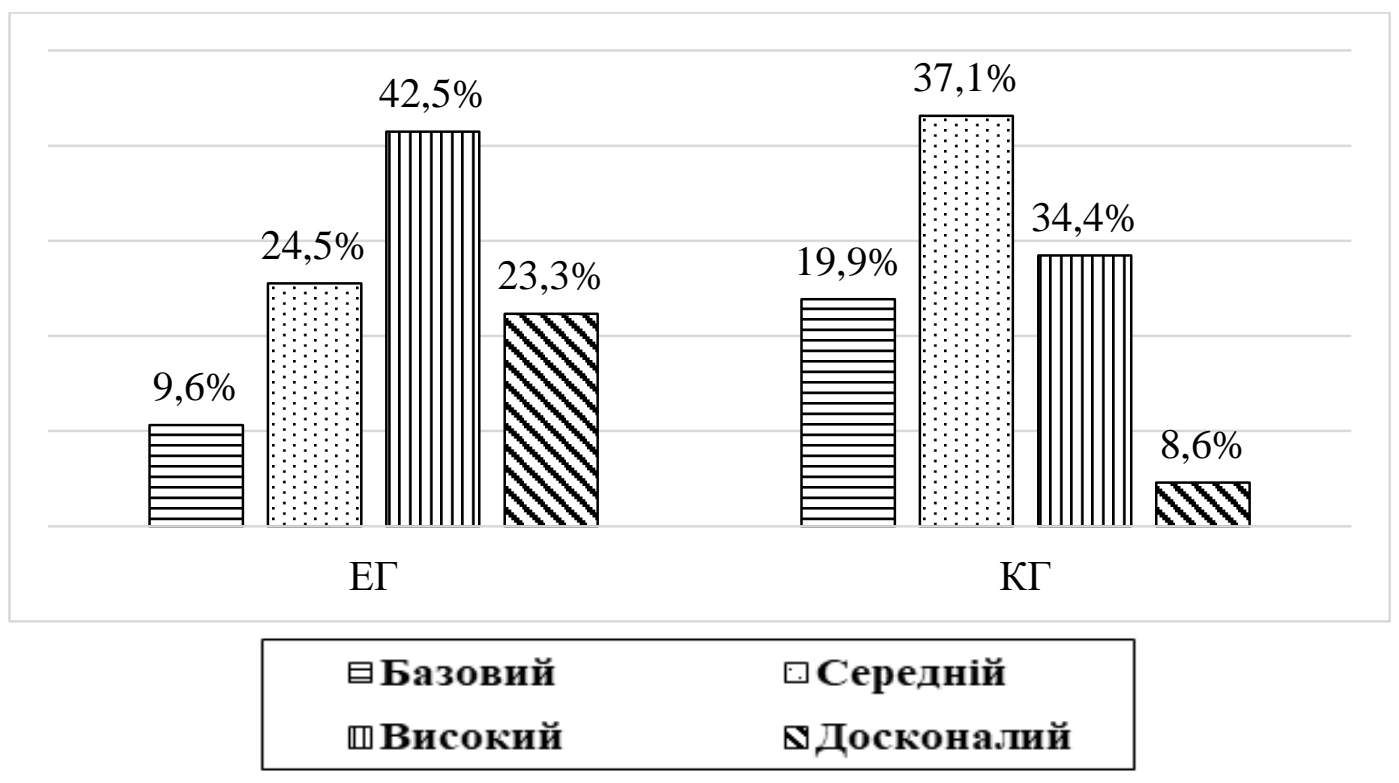

Рис. 2. Діаграма рівнів для ЕГ і КГ після експерименту

Спостерігаємо позитивну динаміку в обох групах. Водночас потрібно перевірити статистично, чи різними є результати оцінки середніх. Застосувавши пакет аналізу табличного процесора MS Excel, маємо наступні результати (табл. 5).

Таблиця 5

Оцінка середніх (після експерименту)

\begin{tabular}{|l|l|l|}
\hline $\begin{array}{l}\text { Двовибірковий т-тест } \\
\text { з різними дисперсіями }\end{array}$ & $\mathbf{K \Gamma}$ & $\mathbf{E \Gamma}$ \\
\hline Середнє & 68,743119266 & 81,60638298 \\
\hline Кількість & 314 & 307 \\
\hline Різниця середніх гіпотези $\mathrm{H}_{0}$ & 0 & \\
\hline t-статистика (експериментальне) & $-4,86327208$ & \\
\hline t критичне двостороннє & 1,972331676 & \\
\hline
\end{tabular}

За аналізом таблиці бачимо, що на рівні значущості $0,05 T_{\text {крит. }}=1,97 \mathrm{i}$ воно менше за модуль $T_{\text {eксn. }}=-4,86$. Це означає, що на виході 3 педагогічного експерименту вибірки статистично різні, і це не можна пояснити випадковими причинами.

Динаміка показника для ЕГ була кращою: у цій групі відбулося збільшення високого та досконалого рівнів на 23,4\% та $14,9 \%$ відповідно, у КГ таке збільшення є статистично меншим 20,8\% та 4,4\% відповідно. Серед чинників, які сприяли такому покращенню бачимо посилене використання інформаційних (електронних, дистанційних, мобільних) технологій навчання та постійне залучення інформаційно-освітнього середовища ЗВО для виконання 
самостійних завдань. Також слід відзначити удосконалення змісту дисципліни «Інформаційні технології», де були передбачені значна кількість завдань на роботу з різними видами текстів, структурою електронних джерел, вивчення особливостей функціонування сучасних систем повнотекстового пошуку, функціонування соціальних мереж, організації чатів, створенню блогів тощо.

\section{Висновки 3 дослідження і перспективи подальших розвідок у цьому} напрямі. Результати педагогічного експерименту свідчать про принципову придатність цифрових технологій і продуктів для використання в освітньому процесі ЗВО, нами встановлено зв'язок між їх упровадженням і формуванням у студентів пізнавальної мотивації до дисциплін, що вивчаються, зростанням їх пізнавальної активності та інтересу до моделювання, а також кількісних методів. В якості одного 3 напрямків подальших досліджень зазначимо розробку дидактичних умов для ефективного використання цифрових продуктів освітнього призначення, створених на основі цифрових технологій, особливої уваги заслуговують механізми корекції процесів розуміння і засвоєння студентами досліджуваного матеріалу з різних дисциплін з урахуванням рівня розвитку їх інформаційно-цифрової культури.

Таким чином, процес цифровізації зачіпає всі компоненти методичних систем викладання фахових дисциплін у ЗВО, а цифрові технології та продукти можуть виступати інструментом модернізації вже функціонуючих методичних систем. Актуальною залишається проблеми вдосконалення методики навчання студентів фахових дисциплін в умовах цифровізації та різноманіття цифрових продуктів, а також уточнення безлічі критеріїв ефективності використання нових цифрових технологій.

\section{СПИСОК ВИКОРИСТАНИХ ДЖЕРЕЛ}

1. Виды сред в образовании. Курс подготовки модераторов для системы дистанционного обучения (2015) / Под. рук. Е. С. Полат. URL : http:// courses.urc.ac.ru/eng/u7K9.html

2. Жалдак, М. І. (2012). Педагогічний потенціал інформатизації навчального процесу. Оцінювання якості програмних засобів навчального призначення для загальноосвітніх навчальних закладів : монографія. Київ.

3. Лапчик, М. П. (2013). На пути к smart-образованию. Информатика и образование, 2 (241), 3-9.

4. Морзе, Н. В. (2004). Методика навчання інформатики : У 3 ч . / 3 ред. акад. М.I. Жалдака. Київ : Навчальна книга. Ч.І. : Загальна методика навчання інформатики.

5. Спірін, О.М.(2007). Теоретичні та методичні засади професійної підготовки майбутніх учителів інформатики за кредитно-модульною системою : монографія. Житомир : Вид-во Житомир. держ. ун-т ім. І.Франка. $25-29$.

6. Цідило, I. (2011). E-Learning: понятійно-категорійний аналіз. Молодь і ринок, 12 (83),

Професіоналізм педагога: теоретичні й методичні аспекти. - Вип. 16. - Слов'янськ, 2021. 


\title{
THE RESULTS OF THE INTRODUCTION OF DIGITAL TECHNOLOGIES IN THE TRAINING OF FUTURE PROFESSIONALS IN HIGHER EDUCATION
}

\author{
Inna Kharchenko, \\ Doctor of Pedagogical Sciences, \\ Associate Professor of the Department of State and Legal \\ Disciplines and Ukrainian Studies, \\ Sumy National Agrarian University \\ Sumy, Ukraine \\ ORCID ID 0000-0010-0111-0125 \\ kharchenko-inna@ukr.net \\ Inna Shyshenko, \\ Candidate of Pedagogical Sciences, \\ Associate Professor of the Department of Mathematics \\ Makarenko Sumy State Pedagogical University \\ Sumy, Ukraine \\ ORCID ID 0000-0002-1026-5315 \\ shiinna@ukr.net
}

\begin{abstract}
The leading task of modern higher education is the introduction of digital technologies in the educational environment, which will enable each future specialist to build an individual educational trajectory that he needs to achieve his professional goal and realize himself in the profession and society. Therefore, the construction of the educational process in the free economic education on the basis of the organization of information and educational environment is one of the possible ways to develop vocational education.

Scientists have convincingly proved that the introduction of digital technologies in the educational process of free economic education involves the rapid updating of educational content in the context of scientific development; qualitative transformation of teaching methods and forms; increasing the amount of independent work for each individual student; creating opportunities for self-control of the quality of acquired knowledge.

The article presents the results of the introduction of digital technologies in the educational process of higher education.

Within the framework of the specially created information and educational environment of higher education, the possibility of using modern information technologies and in-depth integration of specialized professional means with high-quality information support of all educational components is realized. The experimental educational process was structured in such a way that students' knowledge, professional skills and abilities required for the future professional activity of a specialist are transformed by means of digital technologies into a high level of information and digital culture.

The dynamics of the indicator for the experimental group was better, and among the factors that contributed to this improvement, we see the increased use of information (electronic, distance, mobile) learning technologies and the constant involvement of information and educational environment to perform independent tasks. It should also be noted the improvement of the content of the discipline "Information Technology", which provided a significant number of tasks to work with
\end{abstract}


different types of texts, the structure of electronic sources, studying the functioning of modern fulltext search systems, social networks, chats, blogs and more.

Key words: professional training; digital technologies; pedagogical experiment; information and digital culture; future specialists.

\section{REFERENCES}

1. Vidy sred v obrazovanii. Kurs podgotovki moderatorov dlya sistemy distantsionnogo obucheniya (2015). [Types of environments in education. Training course for moderators for the distance learning system] / Pod. ruk. Ye. S. Polat. URL : http:// courses.urc.ac.ru/eng/u7K9.html [in Russian].

2. Zhaldak, M. I. (2012). Pedahohichnyy potentsial informatyzatsiyi navchalnoho protsesu. Otsinyuvannya yakosti prohramnykh zasobiv navchalnoho pryznachennya dlya zahalnoosvitnikh navchalnykh zakladiv [Pedagogical potential of informatization of educational process. Quality assessment of educational software for secondary schools]. Kyiv, 2012. [in Ukrainian].

3. Lapchik, M. P. (2013). Na puti k smart-obrazovaniyu [On the way to smart education]. Informatika i obrazovaniye, 2 (241), 3-9. [in Russian].

4. Morze, N. V. (2004). Metodyka navchannya informatyky [Methods of teaching computer science] : U 3 ch . / Z red. akad. M. I. Zhaldaka. Kyiv : Navchalna knyha. CH. I. : Zahalna metodyka navchannya informatyky [General methods of teaching computer science]. [in Ukrainian].

5. Spirin, O. M. (2007). Teoretychni ta metodychni zasady profesiynoyi pidhotovky maybutnikh uchyteliv informatyky za kredytno-modul'noyu systemoyu [Theoretical and methodical principles of professional training of future teachers of informatics on credit-modular system. Zhytomyr. derzh. un-t im. I. Franka. Zhytomyr [in Ukrainian].

6. Tsidylo, I. (2011). E-Learning: ponyatiyno-katehoriynyy analiz [E-Learning: conceptual and categorical analysis]. Molod i rynok, 12 (83), 25-29. [in Ukrainian].

Матеріали надійшли до редакції 15.10.2021 р. 